\title{
A Review on Possibility of Antifungal Agents Having antibacterial Activity
}

\author{
Popoola BM* \\ Department of Microbiology, University of Ibadan, Nigeria
}

Submission: May 09, 2017; Published: May 24, 2017

"Corresponding author: Popoola BM, Department of Microbiology, University of Ibadan, Ibadan, Nigeria, Email: bukolamargret@yahoo.com

\section{Introduction}

Antimicrobial agents have undergone series of developments both in their origin and wide spread application since many centuries. The effective use of antimicrobial agents has been known to man, for back as the ancient times, especially for domestic purposes. However, scientific application may be limited to past $2 \frac{1}{2}$ centuries. In the early periods, the search for antimicrobial agents was mainly done on higher plants, the present times however records the era of natural products antibiotics from plants of lower order like bacteria, fungi and Actinomycetes.

One of the major triumphs of medical science in the twentieth century has been the virtual eradication of many infectious diseases. The first of these was the discovery in 1935 of the curative effect red dye prontosil on streptococcal infections. Prontosl was the forerunner of sullfonamides. Although the intact molecule has no antibacterial activity in vitro, in the body, it releases its active components, $\mathrm{p}$-amino benzene sulphonamide (sulphanilamide). The second important discovery, the one that ushered in the golden age of antimicrobial therapy, was the discovery of development of penicillin from culture filtrates of Penicllinnotatum. Although the discovery of penicillin had been made by Fleming in 1929, it was Florey, Chain and their associates at Oxford University who in 1940 demonstrated and published an account of its tremendous potency and the feasibility of its extraction from culture fluids. A few of the useful antibiotics, such penicillin A, were entirely fortuitous discoveries of streptomycin in 1944 to the present, the search for such agents has been a highly planned scientifically designed effort.

The importance antimicrobial agents in various field of study is worth mentioning, and their uses are notable in microbiology, medicine, pharmacy and pharmaceutical industries, as chemotherapeutic agents in the treatment of disease and as preservatives in many type of pharmaceutical and cosmetic products Russell et al. [1].

\section{Antifungi Agents}

Antifungal agents may be defined as compounds that cause fungi to fail to thrive. Such a broad definitions sweeps from compounds that kill all forms of lie to agents that appear to affects only fungi adversely.

These agents are often classified into three groups depending on their site of action. The polyenes interacts with fungal membrane-building blocks; azoles inhibit the synthesis of ergosterol, the key fungal sterol; and 5-flourocytosine is an inhibitor of fungal macromolecular synthesis. These agents were developed based on an understanding of the fungal life cycle and weaknesses and the same approaches are used by the organisms themselves to developed resistance.

\section{Possibility of Antifungal Agents Having Antibacteria Activity}

Normally antifungal agents in themselves are expected not to have antibacterial activity, but some of the synthetic and natural antifungal agents have been demonstrated and seen to have antibacterial activity, two antimicrobial neolignans (Magnolol and Isomagnolol) were isolated from roots of Sassafras randaiense. The extract when tested demonstrated antimicrobial activities against bacteria and fungi. The roots of Plumbago zeylanica was reported to contain plumbagin which is lethal to a wide spectrum of bacteria and some pathogenic fungi like Aspergillus niger, Aspergillus flavus and Candida albicans $[2,3]$.

Akinyanju, et al. [4] demonstrated that the hot water extracts of leaves of Acalyphatorta showed significant inhibitory effect in vitro against Staphylococcus aureus, Pseudomonas aeroginosa, Escherichia coli, Klebsiellasp, Salmonella paratyphii, Proteus sp, Serrantiamer cescens and Bacillus sp. The hot water extract of the leaves was also shown to have fungi activity.

Kern and Cardllina (1982) reported the use of various species of osmorhiza being employed for the treatment of 
colds, pneumonia, sore throats and stomach aches by natives of America. Ripe and unripe Carica papaya fruits extracts have been reported to show significant antibacterial activity on Staphytococcus aureus. Bacillus subtilis, Escherichia coli and Pseudomonas aeroginosa [5]. Bahadur and Shulda (1983) reported the use of Thalictrumjavanian in India Folklore medicine. Ocimum gratissmum leaves or the whole herb are popular treatment for diarrhoea [3]. These plant showed both antifungal and antibacterial activities.

Some synthetic compounds like Trosyd, which is normally known as an antifungal agent,are also known to have some antibacterial activity. In the case of Trosyd (tioconazole) \{1-2(2-chloro-3-thenyl)methoxyl-2-4 dichlorophenyl)ethyl-HImidazole\}. It is a synthetic broad spectrum antifungal agent which also has antibacterial activity against several gram positive organisms including Staphylococcus sp and Streptococcus sp (PFIZER). In Vitro it is fungicidal to pathogenic dermatophytes, yeast and other fungi.

Although synthetic and antibiotic antifungal agents are recorded as acting on chemical groups specific to fungi, there reports of several agents such as plant extracts [6] which simultaneously have antibacterial and antifungal activities. As reported by Popoola BM (unpublished) at high concentration canesteen inhibited Bacillus, Klebsiella and Proteus sp. Nystantin inhibited the growth of Staphylococcus sp and Proteus sp. Trosyd also at increased concentration was effective against Bacillus subtilis, Proteus sp, Klebsiella sp and Staphylococcus sp. It is thus possible that some antifungal agents may have antibacterial effect as sited previously. If this is confirmed, then there will be clinical implications.

\section{References}

1. Russel AD, Ijeoma Ahonkhai DY, Rogers (1979) A review Microbiology Applications of Inactivation of antibiotics and otherAntimicrobial Agents. Journal of applied Bacteriology 46(2): 207-245.

2. Akinson N, Brice HE (1956) Antibacterial substances produced by flowering plants Australian. Journal of Experimental Biol Med Science 33(5): 547-554

3. Skinner FA (1956) The Antibiotics in modern methods of plant analysis Peak k and HV (Eds.), 3: 626-725.

4. Akinyanju JA, Owoyale JA, OkanlaE O (1986) Antimicrobial effect of leaf extract of Alcalyphatorta. The state of medicinal plants Research in Nigeria: A sofowora (Ed) proceeding of a conference. Ife Nigeria, 247-251

5. DalzielJ M (1956) Useful plants of West Africa Crown agents for overseas Governments London, p. 27.

6. Emeruwa AC (1982) Antibacterial extracts from Carica papaya fruit extract. Journal of Natural products 45(2): 123-127.

\section{Your next submission with Juniper Publishers will reach you the below assets}

- Quality Editorial service

- Swift Peer Review

- Reprints availability

- E-prints Service

- Manuscript Podcast for convenient understanding

- Global attainment for your research

- Manuscript accessibility in different formats

( Pdf, E-pub, Full Text, Audio)

- Unceasing customer service

Track the below URL for one-step submission https://juniperpublishers.com/online-submission.php 